\section{HANTAVIROSIS: ALGUNAS CONSIDERACIONES DE ESTA NUEVA INFECCIÓN EN EL PERÚ}

\author{
HANTAVIRUS INFECTION: SOME \\ CONSIDERATIONS OF THIS NEW INFECTION IN \\ PERU
}

\author{
Erik J. Jhonston ${ }^{1, a}$, W. Casanova ${ }^{1,2, b}$, \\ Hugo Rodriguez-Ferrucci ${ }^{1,2, c}$
}

Sr. Editor. Luego de los informes preliminares de los primeros casos por Hantavirus en la ciudad de lquitos ${ }^{(1,2)}$, la infección por este género ha cobrado importancia en la Salud Pública por la alta letalidad $(40-60 \%)^{(3)}$. Asimismo, es necesario describir algunos aspectos para establecer las medidas apropiadas de control. Estos pueden resumirse en cuatro preguntas:

1. ¿Qué dificultades existe para su diagnóstico correcto?; el diagnóstico etiológico específico es difícil por la gran cantidad de reacciones cruzadas que ocurren con las pruebas serológicas utilizadas para identificar los diversos tipos de Hantavirus. Si bien las pruebas moleculares y de genotipificación son de mayor utilidad, las proteínas estructurales de varios Hantavirus pueden coincidir en porcentajes mayores a $50 \%$, por lo que es preciso secuenciar más de una proteína para una tipificación precisa. El cultivo viral tiene baja sensibilidad, y requiere un laboratorio de nivel III de bioseguridad, por lo que se prefiere la reacción en cadena de la polimerasa en tiempo real (RT-PCR) por su mayor sensibilidad, pero es preciso contar con todos los reactivos (cortadores) para los Hantavirus del viejo y del nuevo mundo ${ }^{(3)}$.

2. ¿Cuántos tipos de Hantavirus existen en América?; como se puede ver en la Tabla 1, existen varios tipos de Hantavirus que han sido identificados como causa de enfermedad en humanos, así como encontrados en personas asintomáticas y en roedores, de los cuales se desconoce su capacidad patogénica ${ }^{(4,5)}$.

3. ¿El riesgo de enfermedad es igual en una zona urbana que en una rural?; informes preliminares sugieren que en lquitos hubo dos tipos de Hantavirus que causaron enfermedad: el virus Seoul (SEOV) y el virus Río Mamoré ${ }^{(1,2)}$; cada uno adaptado a

\footnotetext{
Universidad Nacional de la Amazonía Peruana. Iquitos, Perú.

2 Dirección Regional de Salud Loreto. Iquitos, Perú.

a Estudiante de Medicina; ${ }^{b}$ salubrista; ${ }^{\mathrm{c}}$ médico epidemiólogo

Recibido: 29-05-12 Aprobado: 26-06-12
}

Tabla 1. Familias de Hantavirus descritas en América.

\begin{tabular}{ll}
\hline CAUSAN ENFERMEDAD & $\begin{array}{c}\text { POTENCIAL DE ENFERMEDAD } \\
\text { DESCONOCIDO }\end{array}$ \\
\hline Sin nombre virus & Limestone Canyon virus \\
Momongahela virus & Playa de Oro virus \\
\hline New York virus & Catacamas virus \\
Black Creek Cabak virus & Calabazo virus \\
Bayou virus & Río Segundo virus \\
Choclo virus & Caño Delgadito virus \\
Andes virus & Pergamino virus \\
Bermejo virus & Alto Paraguay virus \\
\hline Lechiguanas virus & Ape Aime virus \\
Maciel virus & Itapúa virus \\
Oran virus & Jaborá virus \\
Laguna negra virus & \\
Río Mamore virus* & \\
Seoul virus* & \\
Araraquara virus & \\
Juquitiba virus & \\
\hline
\end{tabular}

*Según informes preliminares ${ }^{(1,2)}$

un roedor específico. EI SEOV está íntimamente relacionado con roedores de género Rattus, de distribución urbana; en cambio, el virus río Mamoré está relacionado con el roedor Oligoryzomys microtis de distribución rural ${ }^{(1,2)}$.

4. ¿Es posible la transmisión de persona a persona?; la trasmisión al ser humano ocurre mediante la inhalación de secreciones aerolizadas de roedores infectados, o por contacto directo con dichas secreciones $^{(1,5,6)}$. Se ha descrito que existe trasmisión de persona a persona para el Andes virus (AND) en Argentina. Existen seis linajes del AND que infectan al humano, de los cuales solo el AND sout se transmite de persona a persona. Hasta el momento, no se ha informado de la circulación del linaje AND sout fuera de la zona endémica (provincias del suroeste de Argentina), donde circula su roedor hospedero Oligoryzomys longicaudatus ${ }^{(4)}$. Según los informes preliminares, los tipos de Hantavirus circulantes en Iquitos (SEOV y Río Mamoré virus), hasta el momento no han demostrado tener la capacidad de trasmitirse de persona a persona; por tanto, este tipo de trasmisión es poco probable en nuestro medio.

Esperamos que estos comentarios contribuyan a mejorar la comprensión de esta enfermedad emergente, al enfatizar sobre la dificultad para la identificación etiológica del virus y destacando que la trasmisión de persona a persona, en nuestra población, es poco probable.

Descargo de responsabilidad: las opiniones y afirmaciones contenidas aquí son propias de los autores y no deben interpretarse como posición oficial o que reflejan la opinión del Ministerio de Salud del Perú. 
Fuentes de financiamiento: autofinanciado.

Conflictos de interés: los autores declaramos no tener conflictos de interés.

\section{REFERENCIAS BIBLIOGRÁFICAS}

1. Garcia P, Sinti P, Herrera A, Donaires F, Álvarez C, Arrasco $\mathrm{J}$, et al. Confirmación etiologica de los dos primeros casos de Hantavirosis Humana en el Perú. Rev Peru Med Exp Salud Publica. 2011;28(3):566-7.

2. Dirección Regional de Salud Loreto. Reporte preliminar: Análisis Filogenético de hantavirus detectado en un caso fatal en la ciudad de Iquitos, Noviembre 2011. Iquitos: Centro de Investigación en Enfermedades Tropicales "Maxime Kuczynki"-DIRESA; 2011.

3. Galeno H, Villagra E, Fernandez J, Ramirez E, Mora J. Técnicas diagnósticas de infección humana por hantavirus. Rev Chil Infectol. 2000;17(3):186-91.

4. Jonsson CB, Figueiredo LT, Vapalahti O. A Global Perspective on Hantavirus Ecology, Epidemiology, and Disease. Clin Microbiol Rev. 2010;23(2):412-41.

5. Puerta H, Cantillo C, Mills J, Hjelle B, Salazar-Bravo J, Mattar S. Hantavirus del Nuevo Mundo, ecologia y epidemiologia de un virus emergente en Latinoamerica. Medicina (B Aires). 2006;66(4):343-56.

Correspondencia: Erik Jair Jhonston Vela

Dirección: Calle Napo \# 1298. Iquitos, Perú.

Teléfono: (51) 965960617

Correoelectrónico:erik_jhonston@hotmail.com

\section{AGRESIONES CONTRA EL TRABAJADOR DE SALUD EN TACNA, PERÚ}

\section{ASSAULTS AGAINST HEALTH WORKERS IN TACNA, PERU

\author{
Félix Ancalli-Calizaya ${ }^{1, a}$; Giuliana Cohaila ${ }^{2, a}$; \\ Julio Maquera-Afaray ${ }^{1, a}$
}

Sr. Editor. A propósito del trabajo preliminar sobre Violencia contra médicos; realizado por Tuya-Figueroa y Mezones-Holguín ${ }^{(1)}$. El trabajador de salud que desarrolla su actividad laboral en el medio sanitario está expuesto a sufrir agresiones de tipo físico o verbal. Durante muchos

\footnotetext{
${ }^{1}$ Facultad de Ciencias de la Salud, Universidad Nacional Jorge Basadre Grohmann, Tacna, Perú. ${ }^{2}$ Facultad de Ciencias de la Salud, Universidad Privada de Tacna, Tacna, Perú.

${ }^{a}$ Médico cirujano

Recibido: 12-06-12 Aprobado: 26-06-12
}

años se ha prestado poca atención a las agresiones por parte de los pacientes y familiares; sin embargo, esta situación no debería considerarse como un aspecto normal de la práctica diaria.

El incremento de la violencia se ha expandido a todos los campos laborales, incluyendo al sector salud. Al respecto, la Organización Internacional de Trabajo estableció que el $25 \%$ de las agresiones laborales se producían contra el trabajador sanitario. Desde entonces se ha brindado mayor atención a este problema y algunas instituciones de salud han empezado a medir este fenómeno y sus repercusiones sobre el recurso humano ${ }^{(2-4)}$.

Se realizó un estudio en el Hospital Hipólito Unanue de Tacna que incluyó 185 trabajadores de salud (32 médicos, 45 enfermeras, 76 técnicos de enfermería, entre otros). La recolección de datos se efectuó en un cuestionario basado en la Encuesta exclusiva IntraMed: agresiones contra médicos ${ }^{(5)}$ la cual se aplicó a los trabajadores de salud que laboraban en el hospital en los últimos cinco años.

Los resultados evidenciaron que $77 \%$ del personal de salud sufrió algún tipo de agresión, ya sea verbal (64\%); física (1\%), o ambas (12\%). La agresión fue similar en ambos sexos ( $75 \%$ en varones y $78 \%$ en mujeres). El personal de seguridad sufrió la mayor agresión $(100 \%)$, seguido de obstetrices $(91 \%)$; enfermeras (80\%); técnicos de enfermería (74\%); médicos $(72 \%)$, y farmacéuticos $(40 \%)$. Los servicios con mayor tasa de agresión fueron: el servicio de emergencia $(93,9 \%)$; pediatría (91\%), y psiquiatría (83\%). En la Tabla 1, se muestra el lugar y tiempo de las agresiones.

En $57 \%$ de los casos el agresor fue un familiar; en $13 \%$ fue el mismo paciente; en $19 \%$ por ambos, mientras que en $9 \%$ refirieron agresión por parte de un compañero de trabajo o su superior. Cabe destacar que en $92,5 \%$

Tabla 1. Lugar y tiempo de las agresiones contra el trabajador de salud.

\begin{tabular}{lrr}
\hline & $\mathbf{N .}^{\circ}$ & $(\%)$ \\
\hline Lugar & & \\
$\quad$ Dentro del servicio & 139 & $(97,9)$ \\
$\quad$ Fuera del servicio & 3 & $(2,1)$ \\
Turno & & \\
$\quad$ Mañana & 81 & $(57,0)$ \\
\hline Tarde & 32 & $(22,5)$ \\
Noche & 29 & $(20,4)$ \\
Día de la semana & & \\
Lunes a viernes & 106 & $(74,6)$ \\
\hline Fin de semana & 36 & $(25,4)$ \\
TOTAL & 185 & $(100)$ \\
\hline
\end{tabular}

